\title{
Translation of the Drama Text as an Incomplete Entity
}

\begin{abstract}
It is argued and demonstrated in this paper that the distinctive characteristic of the drama text as an incomplete entity is fundamental and central to this genre and ought to be sufficiently highlighted by drama translation scholars and placed at the centre of the debate in the same stead as performability and speakability. It is further argued and suggested that drama translators and drama translation scholars could increasingly focus their attention (thereby ceasing to concentrate exclusively on the performability and speakability dimensions of the play) on the reading strategies of the other persons involved in the drama communication chain in order to determine to what extent the translator can draw from them to more effectively formulate his own reading and transfer strategies.
\end{abstract}

Suh Joseph Che

From the perspective of poststructuralist or deconstructionist approaches to translation, any creative work of art, particularly literature, can be considered to be of an open nature, often subject to multiple or diverse interpretations by the target audience. From this perspective, it can be said that to some extent, such open texts are incomplete as the target audience plays a major role in enriching and completing them (Umberto Eco 1985). However, of all the literary genres, the drama text is an incomplete text par excellence, whose incomplete nature has a significant incidence on its translation.

Bassnett (1991:100) has argued that if the notion of the gestic text is maintained and considered as fundamental to theatre texts, then 
the task of the translator becomes superhuman-he or she is expected to translate a text that a priori in the source language is incomplete, containing a concealed gestic text.

And to her, what compounds discussion on this issue amongst scholars is the fact that whereas some consider that the responsibility of decoding the gestic text lies with the performers, the assumption in the translation process is that this responsibility can and is often assumed by the translator sitting at a desk and imagining the performance dimension.

Demarcy (1973:369) and Koustas (1988:131) consider the mise en scène as the pivotal element around which all the other theatrical elements are structured, and other scholars like Pavis maintain that where translation for the stage is concerned "real translation takes place on the level of the mise en scène as a whole", adding that:

Translation in general and theatre translation in particular has changed paradigms: it can no longer be assimilated to a mechanism of production of semantic equivalence copied mechanically from the source text. It is rather to be conceived of as an appropriation of one text by another. Translation theory thus follows the general trend of theatre semiotics, reorienting its objectives in the light of a theory of reception.

(Pavis 1989:25-45)

Bassnett disagrees with the above assertions by Pavis arguing that:

Pavis still insists on a hierarchical relationship, repeating the notion that 'real' translation takes place on the level of the mise en scène, in other words, that a theatre text is an incomplete entity. This means that his unfortunate interlingual translator is still left with the task of transforming unrealized text $\mathrm{A}$ into unrealized text $\mathrm{B}$, and the assumption here is that the task in hand is somehow of a lower status than that of the person who effects the transposition of written text into performance [...]. Translation is and always 
has been a question of power relationships, and the translator has all too often been placed in a position of economic, aesthetic and intellectual inferiority.

(Bassnett 1991:100-101)

In this paper it is argued, contrary to Bassnett, that the drama text is indeed an incomplete entity. Furthermore, the issue of the status of the drama translator is viewed from a different perspective. It is asserted that, though operating at different stages in the drama communication chain, the communication roles of the drama translator and director are distinct but share an identical purpose and that the relationship between these key persons ought to be viewed from the perspectives of collaboration and complementarity rather than inferiority or superiority in status.

Drama specialists and scholars are unanimous in asserting that a play is an incomplete composition and that

le dramaturge écrit pour qu'un autre (ou une collection d'autres) parle à sa place et actualise par les gestes le sens de son œuvre" [The dramatist writes for another person (or group of persons) to speak in his place and actualize the message of his work through gestures]

(Ubersfeld 1996:18)

Thus, the dramatist writes the play for someone else or other persons to speak in his place and actualize the message of his work through action. In the same vein, Batty (2000:68) has pointed out that

conventionally the playwright's authorship of the theatrical event ends with the production of a written text and s/he is subsequently reliant upon groups of interpretative artists to complete the work and produce the performance text. 
Similarly, Mbom (1988:197) asserts that:

L'oeuvre dramatique représentée n'appartient plus à son auteur initial seul. Elle est le produit collectif de quatre créateurs: l'auteur, le metteur en scène, les acteurs et les spectateurs. Ne pas comprendre cette réalité aujourd'hui, c'est continuer à se vautrer dans l'empirisme irresponsable et complètement dépassé. Une entente parfaite doit donc s'installer entre les trois premiers créateurs s'ils veulent conquérir le quatrième qui en toute évidence conserve le dernier mot car, la plupart du temps, de sa sanction dépend le succès ou l'échec des trois premiers. [The play when performed no longer belongs to the author alone. It is the collective product of four creators: the author, the producer, the actors and the audience. To ignore this reality, today, is to continue to wallow in irresponsible and completely superseded empiricism. There must, therefore, be a complete understanding and symbiosis between the first three creators if they want to win over the fourth creator who, quite obviously, has the last word, given that most of the time the success or the failure of the first three creators depends on his verdict.]

Thus, the actualization of the play, in other words, the concretization of the message and intention of the playwright as well as the aesthetic dimension of the play depends on the concerted action of several intervening persons. The situation may be diagrammatically represented as follows in Figure 1 below:

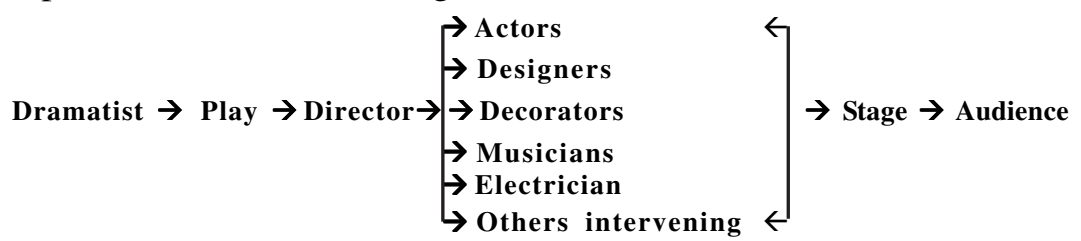

Figure 1: communication chain in drama in a unilingual situation 
Consequently, the problem of performability or speakability notwithstanding and whether the drama translator adequately resolves it or not in the written drama text he has translated, the fact remains that, contrary to a novel, a short story or a poem, in order for the translated version to be performed and for it to be consumed by the target audience just as in the case of the original, it must transit through the other persons involved in the drama communication chain (director, actors, designers, musicians, electricians, etc), who are the people who manipulate, tailor and fine-tune it in accordance with the specific circumstances of each theatricalisation or in order to position the dramatic text within a proposed mise en scène. Zuber-Skerritt (1988:485) underscores this situation by asserting that

as well as being a literary text, the translation of drama as a performing art is mainly dependent on the final production of the play on the stage and on the effectiveness of the play on the audience. A theatre performance is subject to changes according to audience reaction, acting, performance, physical environment and other factors.

Moravkova (1993:35) corroborates Zuber-Skerritt's assertion by stating that:

L'auteur de la traduction n'est pas capable d'influencer complètement le résultat de sa création; c'est un des traits spécifiques du travail des traducteurs de drames. Ce sont les autres participants de la réalisation scénique, le metteur en scène, les acteurs, l'auteur de la musique, l'auteur des décorations, qui influencent le résultat final. [The author of the translation cannot completely influence the result of his creation; this is one of the specific characteristics inherent in the task of the drama translator. They are the other participants involved in the staging of the play- the producer, the actors, the musician, the decorator- who influence the final result.] 
It is for this reason, therefore, that one can argue that the distinctive characteristic of the dramatic text as an incomplete entity is fundamental to this genre and ought to be sufficiently highlighted by drama translation scholars and equally placed at the centre of the debate in the same stead as performability and speakability which have been the focus of drama translation scholars for over three decades. This paper, therefore, analyzes the distinct roles of the drama translator and director, and examines in greater detail, from a theoretical stand-point, the communication situation of the drama translator and the director in order to highlight the implications on the communication of the content and form of the play by both of them to the target audience.

Unlike the unilingual director, actors, other persons in the communication chain as well as the source text audience who are ignorant of the foreign culture and are unaware of the problems of intercultural communication, the drama translator is an expert in crosscultural communication and his bicultural competence is a basic prerequisite for his work. He effects intercultural communication professionally to communicate the contents and beauty of what is being transmitted through the work and the intention/purpose behind the communicative act of the playwright. In professionally interrelating the two cultures, the translator is in a position to compensate for any possible inappropriate preconceptions and projections on the part of the target audience as well as the inadequate active behaviour patterns such preconceptions and projections may lead to.

Apart from the drama translator, the focus here is specifically on the director of the play (to the exclusion of the other persons in the drama communication chain) for several reasons. In effect, the various components of a theatrical performance involving the intervention of different artists (actors, designers, musicians, electricians, etc) are brought together and coordinated by the director. Concretely, the production of a play goes through a stage of directing in which the director guides them by ensuring that all body movements, intonation, speech rhythm, lighting effects, stage decorations, etc conform to the entire discourse of the production and ties in with the various parts of 
the play (acts, scenes, tableaux, sequences, etc) in order to communicate to the audience the effect intended by the dramatist. In this regard,

Batty (2000:68) again points out that,

the ultimate control over the manner in which the performance text will achieve its utterance lies, of course, in the hands of the director, and it is s/he who authors the play as it is offered to the public.

In addition to the roles of coordination and directing ensured by the director, the latter can equally be considered the real interpreter of the play considering that his reading of the text and his manner of relating the various scenic elements are very determining in revealing the full potential of the message/effect of the play and their communication to the audience. The director interprets the words of the original play or those of the translated version into the language of movement and gesture, of voice and facial expression. In short, he 'translates' them into visible and audible human emotion.

Drama specialists have sufficiently underscored this central and prominent role of the director in the drama communication chain. Pavis (1987:246), for instance, asserts that,

toute mise en scène est une interprétation du texte (ou du script), une explication du texte en acte; nous n'avons accès à la pièce que par l'intermédiaire de cette lecture du metteur en scène" [Every production is an interpretation of the text (or the script), a transformation of the text into action. We only have access to the play through this reading of the producer].

Dort (1971:55-56) on his part equally emphasizes the primordial role of the director by stating that,

il devient l'élément fondamental de la représentation théâtrale: la médiation nécessaire entre un texte et un 
spectacle. [He is the fundamental element in the performance: the mediation necessary between the text and the performance].

The dramatist thus writes his play for a target audience but does not necessarily go on to direct or act it out for them. Rather, he entrusts the director and others with the responsibility of interpreting and communicating the work to the target audience through action.

In effect, in drama communication the director occupies, in an intralingual situation, a mediating and communicative position similar to that of the translator in an interlingual situation. He is the intermediary between the playwright and the audience. He is the one who is responsible for interpreting the message/effect to be transmitted to the audience through staging and theatrical performance. To this effect he, in principle, in his conception and endeavour to stage the play strives to capture the dramatist's ideas and message in order to concretise them on stage. In so doing he ensures that it is his actors who are transformed in function of the play and not the play in function of the director, or else the outcome would be the performance of another work and no longer that of the dramatist interpreted. In this regard, his mission and responsibility towards the dramatist, the text and the audience could be considered identical to those of the drama translator.

However, in an interlingual communication situation the communication process is more complex. After translating the original incomplete/unrealized play, the drama translator (as the new author) is also obliged in his turn, just as the dramatist did with the original, to entrust the director with the responsibility of completing, actualizing and communicating through the voices and gestures of the actors the message/effect which he has painstakingly interpreted and re-expressed in the target language. It is evident in such a scenario as illustrated in Figure 3 below that the mediating communication roles of the drama translator and director between the dramatist and the audience are complementary given that in the final analysis, the message/effect of the original play as received by the audience in the target language/ culture is the fruit of the joint transfer endeavour of the drama translator and the director. 


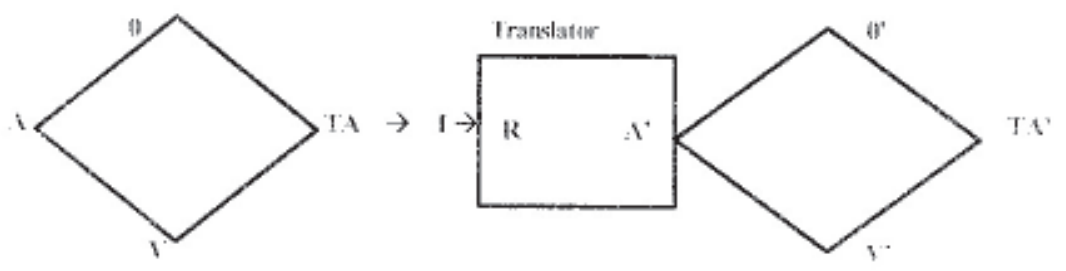

Figure 2: Normal translation communication circuit from one language to another

$A=$ Author of the source text (i.e., original text)

$\mathrm{TA}=$ Target Audience (of the source text)

$\mathrm{O}=$ Object communicated by A to TA (e.g. message, feelings, effect, etc)

$\mathrm{V}=$ Vector (i.e., the language as well as the spatial and temporal conditions through which $\mathrm{O}$ is communicated to TA by A).

$\mathrm{I}=$ Initiator (i.e., the person who has commissioned the translation).

$\mathrm{R}=$ Receptor. The translator is a receptor as he is only an incidental TA given that the message is not originally intended for him.

A', TA', O' and V' are the author, target audience, object and vector respectively in the foreign language/culture.

Figure 2 represents a normal translation communication circuit from one language to another in which the translator is both TA and $\mathrm{R}$ as well as A' in the foreign language/culture. This could be considered the normal translation communication circuit in the translation of a novel, poem, short story or a play that ended up not being performed but simply read like any of the other literary genres.

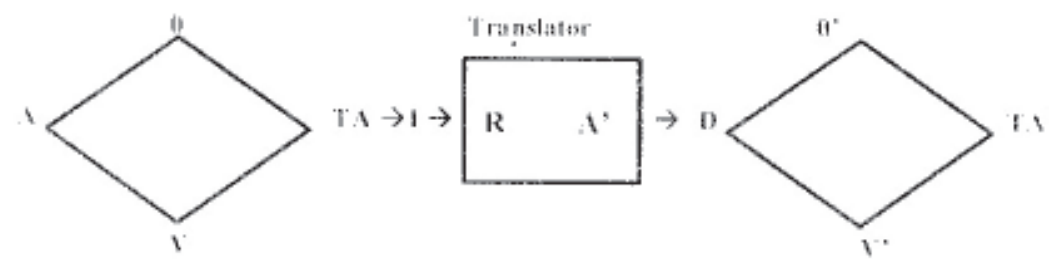

Figure 3: Drama translation communication circuit from one language to another

$\mathrm{D}=$ Director 
In Figure 3, in addition to the communication parameters already described in Figure 2, there is a new parameter D (the director of the play) as well as actors, designers, decorators, musicians, electricians, etc (not included in the diagram for purposes of simplification). This diagram makes it apparent that in the material conditions (V') employed by the director (D) to communicate the message/effect $\left(\mathrm{O}^{\prime}\right)$ there are different communication techniques that come into play between the translator and the new target audience (TA') introduced by D and no longer the translator as was the case in the normal communication situation presented in Figure 2.

The above diagram, from a theoretical stand-point, shows in effect that while the drama translator bears in mind and indeed strives to visualize TA' at the time he is effecting the translation, in the final analysis the first person to receive the translation is the director (D) who substitutes himself for the translator and in turn communicates the message/effect, according to his own personal interpretation, to the audience initially targeted by the translator. This prevailing situation is underscored by Gravier (1973:41) when he asserts that,

chaque auteur stylise à sa manière le langage qu'il emploie, [...]. Il appartient donc au traducteur de percevoir cette stylisation et cette individualisation et de les rendre sensibles dans le texte qu'il va proposer au metteur en scène et aux différents comédiens. [Each author stylizes the language he uses in his own way, [...]. It is up to the translator to detect this stylization and idiosyncratic usage and to make it manifest in the text he offers to the producer and the various actors].

The most immediate focus of the drama translator is therefore the director and the actors with the audience taken into account only through them. Thus, one of the implications of the incomplete nature of the drama text is its dual destination which is often not sufficiently discussed and highlighted by drama translation scholars. When writing the play, the dramatist targets both the director and the audience. Given that everything being equal a play is normally meant to be performed, 
the dramatist normally targets in the first instance the director (and actors etc) with specific instructions in the form of stage directions detailing and indicating to the director the orientation to adopt in his conception of the production and eventual theatrical performance before the audience.

Some drama specialists (Helbo 1987, Pavis 1992, 2000, Ubersfeld 1996) consider stage directions as an essential and integral part of the drama text and even as a sort of metatext which determines and conditions the rest of the text. Consequently, the director is considered 'faithful' to the dramatist when he respects them in his interpretation and staging of the play. It is, therefore, only after attaining the first target (the director) that the play continues its journey and ends up before the audience (the second target).

This dual destination of the drama text implies an incidence on the manner in which the drama translator would communicate the message to each of the targets insofar as, on the one hand, he would have to visualize the director and the actors at work and word the message in such a way that the text is performable to them and, on the other hand, the audience and their reaction at the time they watch the play. Thus, he would not translate in the same way the instructions (stage directions) meant only for the director (and his actors) and the story together with its aesthetic embellishment meant for the audience. In this regard, Hamberg (1969:91-92) has pointed out that "a translator who is careless with stage instructions often places the stage manager in an unfavourable position".

Unfortunately, when drama translation scholars talk about drama translation the tendency quite often is to consider only the audience as the target of the drama piece to the exclusion of the director, who is thus relegated to the background, whereas the appropriate/accurate reconstitution and actualization of the message and aesthetic quality of the work by the latter equally depends on his perfect understanding and meticulous and strict execution of the dramatist's instructions contained in the stage directions. 
From a theoretical perspective, therefore, the communication situation of the drama translator is quasi identical to that of the director in that, even though intervening at different stages of the drama communication chain, the translator is both receptor and new author of the message of the play, and the director on his part is also both the target and new author of the message of the same play. In other words, a director usually stands in-between the written text and the performance text as a sort of surrogate author; his role is therefore analogous to that of the translator.

Such a situation implies close collaboration and complementarity between them, given that, as stated earlier, in the final analysis the message and full potential of the original play as received by the audience in the target language/culture is the result of their joint transfer endeavour.

In this regard, Gravier (1973:48) underscores the nature of the relationship between the drama translator and the director by maintaining that:

une sorte de complicité devrait s'établir entre le traducteur et le metteur en scène. Le traducteur doit aider le metteur en scène à élucider les questions que lui pose le texte. Mais le metteur en scène a une idée de manœuvre, au moment où il s'attaque à la pièce. Et le traducteur doit assister aux répétitions, il tente d'entrer dans les vues du metteur en scène, dont il est devenu le collaborateur. [a sort of symbiosis ought to exist between the translator and the director. The translator should help the director to elucidate the issues that the play raises. The director, on his part, must have an idea of how he is to manoeuvre when putting on the play. And the translator who is his collaborator should attend the rehearsals and try to share his conception of the performance.] 
This view is supported by Moravkova (1993:36) who also asserts that:

\begin{abstract}
Chaque oeuvre dramatique propose au traducteur plusieurs possibilités. Il a la possibilité de choisir l'une des plusieurs interprétations. Dans cette phase du travail, il ressemble à un metteur en scène qui choisit une des possibilités d'après sa vision de la mise en scène. Dans le cas idéal, un traducteur de drame est en contact avec le metteur en scène et les participants de la réalisation scénique. Un résultat réussi dépend d'une conception unique de tous les participants. [Each play offers the translator several possibilities. He has the possibility to choose one of the many possible interpretations. During this phase of his work, he is like the director who chooses one of the many possibilities according to his conception of the production. Ideally, the drama translator is in contact with the director and the production team. A successful performance depends on a convergent conception by all the intervening parties.]
\end{abstract}

Another implication of such collaboration and complementarity for the drama translator and drama translation researcher is that it could be more fruitful to examine closely and analyze what directors and performers actually do to the text for it to be performable or for it to be performed and then from that stand-point to determine and describe the criteria that render the text performable. It is, thus, underscored here that the drama translator or scholar definitely stands to gain deeper insight into the drama translation phenomenon by getting involved in the process of transforming the translated text into a dramatic event which is what the audience actually live when they go to watch a performance.

Finally, the incomplete nature of the drama text gives rise to various levels of reading of the same text by different persons involved in the drama communication chain, a situation which further underlines the need for collaboration between them. In effect, recent work in theatre semiotics (Bassnett 1991:106) has revealed variations in the 
reading of drama texts, for example, the pre-performance literary reading which involves an imaginative spatial dimension by the individual as in the reading of a novel, the director's reading which involves shaping the text within a larger system of theatrical signs, a performer's reading which focuses on one role and other similarly focused readings by lighting technicians, designers, etc. In a more recent study, Aaltonen (2000:6) corroborates and reiterates this by asserting that

readers, translators, directors, actors designers and technicians all construct their own readings, which are then coordinated in the stage production for audiences to use as basis for their meaning construction.

Also emanating from this variation in the reading of the drama text and therefore equally conferring on this genre its distinct nature are the resultant models of expression or 'languages' inherent in the same text which have to be decoded and actualised. In effect, in drama communication, in addition to the words or utterances, there are also the languages of gesture, costumes, make-up, décor, props, sound effects, lighting, etc to be taken into account by all those involved (including the drama translator) in the drama chain. In this regard, it can, therefore, be asserted that this clearly suggests that drama translators and drama translation scholars could increasingly focus their attention (thereby ceasing to concentrate exclusively on the performability dimension of the play) on the reading strategies of the other persons involved in the chain and to determine to what extent the translator can draw from them in the more effective formulation of his own reading and transfer strategies.

Given the distinct but complementary roles of the drama translator and director as described and highlighted above, and the fact that in interlingual communication the director accedes to the original work only through the translator, it equally implies that it is the duty of the drama translator as a true specialist at translating to talk to the director, if the need arises, into accepting his expert view of textual reality and securing from him maximum formal leeway. In other words, 
in his professional relationship with the director, it is necessary for the translator to secure or earn the director's trust and respect as a specialist at mediated interlingual communication.

\section{References}

Aaltonen, S. (2000) Time-Sharing on Stage: Drama Translation in Theatre and Society, Clevedon: Multilingual Matters Ltd.

Bassnett, S. (1998a) 'Translation Across Culture', Language at Work, British Studies in Applied Linguistics 13: 72-85.

(1998b) 'Still Trapped in the Labyrinth: Further Reflections on Translation and Theatre', in S. Bassnett \& A. Lefevere (eds) Constructing Cultures: Essays in Literary Translation, Clevedon: Multilingual Matters, 90-108.

(1998c) ‘The Translation Turn in Cultural Studies', in S. Bassnett

\& A. Lefevere (eds) Constructing Cultures: Essays in Literary Translation, Clevedon: Multilingual Matters, 123140.

(1991) 'Translating for the Theatre: The Case against Performability', TTR 4 (1):99-111.

(1990) 'Translating for the Theatre: Textual Complexities', Essays in Poetics 15:71-84.

(1985) 'Ways through the Labyrinth: Strategies and Methods for Translating Theatre Texts', in Theo Hermans (ed.) The Manipulation of Literature: Studies in Literary Translation, London: Croom Helm, 87-102.

(1980) Translation Studies, London: Routledge. 
(1978) 'Translating Spatial Poetry: an Examination of Theatre Texts in Performance' in J. Holmes et al. (eds) Literature and Translation, Louvain: Acco, 161-176.

Batty, M. (2000) 'Acts with Words: Beckett, Translation, Mise en Scène and Authorship', in C-A Upton (ed.) Moving Target: Theatre Translation and Cultural Relocation, Manchester: St. Jerome, 63-72.

Demarcy, R. (1973) Elements d'une sociologie du spectacle, Paris: U.G.E.

Dort, B. (1971) Théâtre reel, Paris: Seuil.

Eco, Umberto. (1985) Lector in fibula, Paris: Grasset et Fasquelle.

Gravier, M. (1973) 'La traduction des textes dramatiques', Etudes de Linguistique Appliquée: Exégèse et Traduction. Paris: Didier.

Hamberg, L. (1969) 'Some Practical Considerations Concerning Dramatic Translation', Babel 15 (2):91-100.

Helbo, A. (ed.) (1987) Theory of Performing Arts, Amsterdam: John Benjamins.

(1975) Sémiologie de la représentation: théâtre, télévision, bande dessinée, Bruxelles: Editions Complexes.

Koustas, J. (1995) 'Made in Quebec, Reviewed in Toronto: Critical Response to Translated Quebec Theatre', Meta 40 (4):529539.

(1988) 'Traduire ou ne pas traduire le théâtre: l'approche sémiotique', TTR 1 (1):127-138.

Mbom, C. (1988) 'Le théâtre camerounais et les reflets d'une société en pleine Mutation', Théâtre Camerounais, Yaounde: BET \& Co. Ltd., 181-201. 
Moravkova, A. (1993) 'Les problèmes spécifiques de la traduction des drames', Proceedings of III FIT World Congress, London: Institute of Translation and Interpreting, 34-37.

Pavis, P. (2000) Vers une théorie de la pratique théâtrale: Voix et images de la scène 3, Villeneuve: Presses Universitaires du Septentrion.

(1992) Theatre at the Crosssroads of Cultures, London: Routledge.

(1989) 'Problems of translating for the stage: Intercultural and Post-modern Theatre', in H. Scolnicov \& P. Holland (eds) The Play Out of Context: Transferring Plays from Culture to Culture, Cambridge: Cambridge University Press.

(1987) Dictionnaire du theater, Paris: Messidor/Editions Sociales.

(1976) Problèmes de sémiologie théâtrale. Québec: Les Presses de l'Université du Québec.

Ubersfeld, A. (1996) Lire le théâtre I (Nouvelle édition revue), Paris: Belin.

(1978) Lire le theater, Paris: Editions Sociales.

Zuber-Skerritt, O. (1988) 'Towards a Typology of Literary Translation: Drama Translation Science', Meta 33 (4):485-490. 